\title{
Effects of habitat alteration and disturbance by humans and exotic species on fosa Cryptoprocta ferox occupancy in Madagascar's deciduous forests
}

\author{
Samuel D. Merson, Luke J. Dollar \\ CedRic Kai Wei Tan and David W. Macdonald
}

\begin{abstract}
Anthropogenic habitat alteration and invasive species are threatening carnivores globally. Understanding the impact of these factors is critical for creating localized, effective conservation programmes. Madagascar's Eupleridae have been described as the least studied and most threatened group of carnivores. We investigated the effects of habitat degradation and the presence of people and exotic species on the modelled occupancy of the endemic fosa Cryptoprocta ferox, conducting camera-trap surveys in two western deciduous forests, Ankarafantsika National Park and Andranomena Special Reserve. Our results indicated no clear patterns between habitat degradation and fosa occupancy but a strong negative association between cats Felis sp. and fosas. Cat occupancy was negatively associated with birds and positively associated with contiguous forest and narrow trails. In contrast, dog Canis lupus familiaris occupancy was best predicted by wide trails, degraded forest and exotic civets. Our results suggest fosas are capable of traversing degraded landscapes and, in the short term, are resilient to contiguous forest disturbance. However, high occupancy of cats and dogs in the landscape leads to resource competition through prey exploitation and interference, increasing the risk of transmission of potentially fatal diseases. Management strategies for exotic carnivores should be considered, to reduce the widespread predation of endemic species and the transmission of disease.
\end{abstract}

Keywords Ankarafantsika, deforestation, Eupleridae, fosa, feral cat, habitat degradation, invasive species, Menabe

Supplementary material for this article is available at https://doi.org/10.1017/So03060531800100X

SAMUeL D. MERson (Corresponding author, (1) orcid.org/0000-0003-1544-4790) Zoological Society of London, Outer Circle, Regent's Park, London, NW1 4RY, UK. E-mail samuel.merson@zsl.org

LUKE J. DOLlaR ${ }^{*}$ Nicholas School of the Environment, Duke University, Durham, North Carolina, USA

Cedric Kai Wei Tan and David W. Macdonald Wildlife Conservation Research Unit, Department of Zoology, University of Oxford, The Recanati-Kaplan Centre, Tubney House, Tubney, UK

*Also at: Department of Environment \& Sustainability, Center for the Environment, Catawba College, Salisbury, North Carolina, USA

Received 15 January 2018. Revision requested 16 April 2018.

Accepted 24 July 2018. First published online 21 May 2019.

\section{Introduction}

The fosa Cryptoprocta ferox is Madagascar's largest 1 endemic carnivore. The species plays a critical role in ecosystems across Madagascar as an apex predator of lemurs, small mammals, reptiles and birds (Dollar et al., 2007; Hawkins \& Racey, 2008). Weighing 6-7 kg (Hawkins, 1998; Dollar, 2006), male fosas have been estimated to occupy large home ranges of up to $50 \mathrm{~km}^{2}$ (Lührs \& Kappeler, 2013) at low densities of $0.18-0.26$ per $\mathrm{km}^{2}$ in deciduous forests (Hawkins \& Racey, 2005) and 0.20 per $\mathrm{km}^{2}$ in rainforests (Murphy et al., 2018b). Currently categorized as Vulnerable on the IUCN Red List (Hawkins, 2016), fosas are threatened by bushmeat hunting (Golden, 2009; Farris et al., 2015b; Merson, 2018), retaliatory killing in response to poultry predation (Hawkins, 2016; Merson, 2018), exotic species (Gerber et al., 2012b; Farris et al., 2015c) and habitat loss (Gerber et al., 2012a; Farris et al., 2015b).

Deforestation has significantly reduced Madagascar's overall forest cover, and much of the remaining forest is severely degraded (Allnutt et al., 2013; Vieilledent et al., 2018). However, there has been little research on the effects of anthropogenic disturbance on Madagascar's endemic species (Irwin et al., 2010). In addressing these empirical deficits, the fosa is a useful focal species because its innate biological characteristics (large body size and home range, low population density) make it potentially more susceptible to human-caused extinction (Ripple et al., 2014).

Research documenting the fosa's persistence in humandisturbed landscapes is mostly limited to Madagascar's eastern rainforests. Camera-trap studies have reported broad patterns of lower native, and higher exotic carnivore occupancy in more degraded forests (Gerber et al., 2012a; Farris et al., 2014, 2015b; Murphy et al., 2017). However, despite these advances in the knowledge of anthropogenic disturbance in eastern Madagascar, no similar research has yet been published from Madagascar's deciduous forests, a globally important, threatened ecoregion (Waeber et al., 2015).

Deforestation in western Madagascar has reduced much of its deciduous forest cover (Scales, 2012), with high annual rates of loss continuing (Zinner et al., 2014). Many narrow-ranged endemic taxa occupy these forests (Waeber et al., 2015), and are potentially capable of responding differently to anthropogenic change in rainforests compared to deciduous forests 


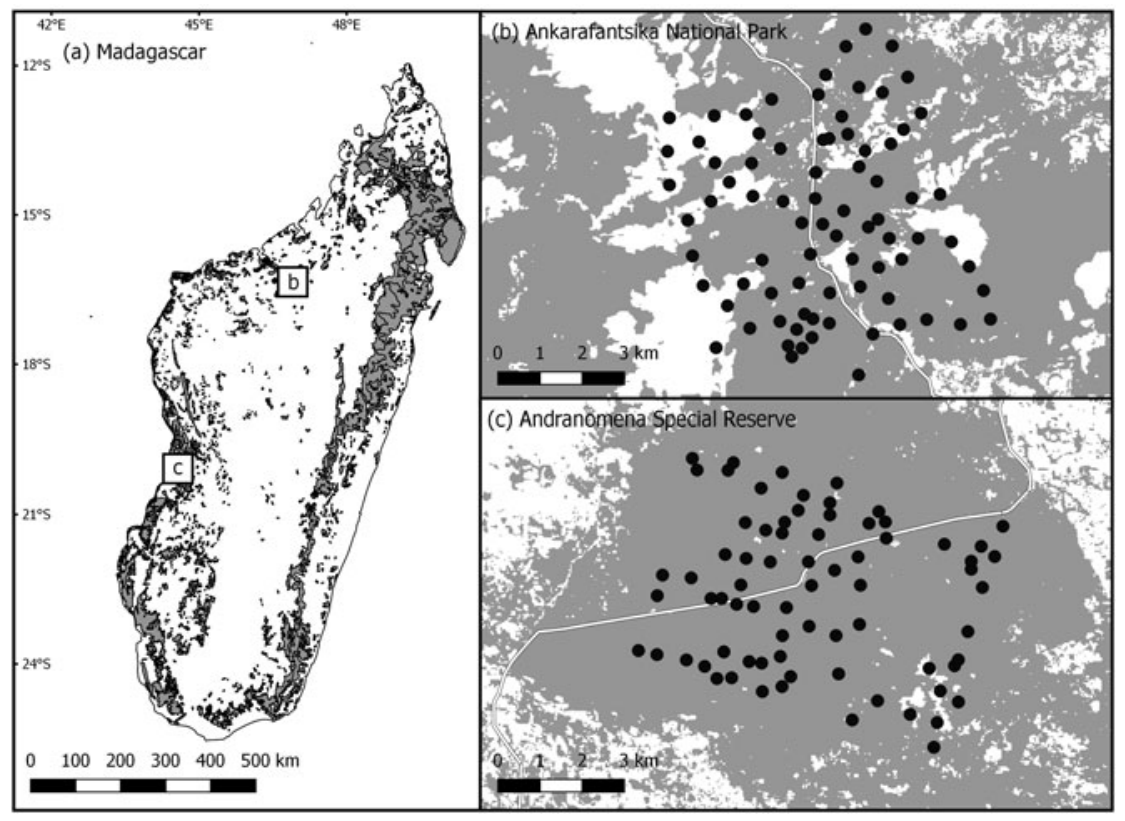

FIG. 1 (a) Forest cover (shaded) and location of study sites in north-west and western Madagascar where the camera-trap surveys were conducted during 2014-2015, with location of camera traps in (b) north-west Ankarafantsika National Park and (c) western Andranomena Special Reserve.
(Gardner, 2009; Irwin et al., 2010). With these species now facing greater anthropogenic disturbance, understanding this relationship is more important than ever.

This study investigated the effects of anthropogenic disturbance on fosas living in deciduous forest. Surveys were conducted in two forests, Ankarafantsika National Park and Andranomena Special Reserve, contrasting in degradation, forest cover and human occupation. Our objectives were to examine (1) the effects of human and exotic species presence on fosa occupancy, (2) the effects of various landscape variables (measures of forest degradation) on fosa occupancy, and (3) differences in fosa occupancy between the two forests.

\section{Study area}

Ankarafantsika National Park is Madagascar's largest continuous dry deciduous forest $\left(1,350 \mathrm{~km}^{2}\right.$; Fig. 1). The $37.73 \mathrm{~km}^{2}$ study site within the Park includeses four villages and is characterized by old-growth forest (defined as continuous forest that has experienced some human disturbance), savannah, raffia plantations and rice fields. It is used recurrently by local people and frequented by exotic species, including the zebu Bos primigenius indicus, free-ranging dogs Canis lupus familiaris and cats Felis sp., bushpig Potamochoerus larvatus, small Indian civet Viverricula indica, and another endemic carnivore, the western falanouc Eupleres major (Merson et al., 2018).

Andranomena Special Reserve $\left(64 \mathrm{~km}^{2}\right)$ is located in the central-western region of Menabe. The $35.45 \mathrm{~km}^{2}$ study site within the Reserve encompasses contiguous, mostly oldgrowth forest, with two villages on its boundary. The area is bisected by a grid system of trails established by the former
Forestry Commission (Fig. 1). Despite the cessation of commercial logging, widespread illegal logging was evident throughout the study site. The Reserve is home to another euplerid, the endemic bokiboky Mungotictis decemlineata.

\section{Methods}

Eighty pairs of camera traps (Cuddeback Ambush IR 1187, De Pere, USA) were placed along trails in Ankarafantsika National Park for 80 days during April-June 2014), and in Andranomena Special Reserve for 35 days during MayJune 2015. Trails were chosen to maximize the detection of fosas and exotic species for occupancy analysis (O'Connell et al., 2010). Camera stations were c. $500 \mathrm{~m}$ apart, improving the detection of $E$. major and $M$. decemlineata, which have smaller home ranges than $C$. ferox. Stations were set up following the methodology of Gerber et al. (2012a). Pairs of independently operated cameras were placed flanking trails, $20-30 \mathrm{~cm}$ above the ground, to improve detection and account for potential camera-trap failure. Camera stations operated for 1-3 months to ensure sufficient data were collected, and to minimize violation of the assumption of population closure for occupancy modelling (MacKenzie, 2006).

\section{Analysis}

We used occupancy modelling to investigate the effects of camera-station level, landscape-level and species-level (i.e. species presence) variables on the probability of fosa presence (MacKenzie \& Nichols, 2004). Photographic data were converted into detection histories (1, detection; o, nondetection) for the fosa, and for key exotic species (Table 1) 
TABLE 1 Forest area and summary statistics of the camera-trap surveys conducted during 2014-2015 in Ankarafantsika National Park and Andranomena Special Reserve, Madagascar (Fig. 1), with the camera-trap station, landscape-level and species-level covariates (i.e. trap success) at each site.

\begin{tabular}{|c|c|c|}
\hline & Ankarafantsika National Park & $\begin{array}{l}\text { Andranomena Special } \\
\text { Reserve }\end{array}$ \\
\hline \multicolumn{3}{|l|}{ Study site and survey summary } \\
\hline Forest area $\left(\mathrm{km}^{2}\right)$ & 1,350 & 64 \\
\hline Survey date & 12 Apr. 2014-12 July 2014 & 20 May 2015-28 June 2015 \\
\hline Camera-trap grid area $\left(\mathrm{km}^{2}\right)$ & 37.73 & 35.45 \\
\hline Mean no. of days camera traps deployed \pm SD & $79.14 \pm 9.24$ & $35.91 \pm 6.18$ \\
\hline Total no. of camera-trap stations & 79 & 69 \\
\hline Mean station spacing $(\mathrm{m})$ & 579.4 & 464.9 \\
\hline Total camera-trap effort (nights) & 6,252 & 2,478 \\
\hline \multicolumn{3}{|l|}{ Camera-trap level covariates ${ }^{1}$} \\
\hline Mean trail width $(\mathrm{m})^{2,3,4}$ & 3.2 & 3.1 \\
\hline Forest type $\mathrm{e}^{3}$ & Various & Various \\
\hline Trail type & Various & Various \\
\hline \multicolumn{3}{|l|}{ Landscape-level covariates ${ }^{1}$} \\
\hline Mean distance to village $(\mathrm{m})^{2}$ & $1,616.9$ & $5,113.9$ \\
\hline Mean distance to forest edge $(\mathrm{m})^{3,4}$ & 357.5 & $2,489.8$ \\
\hline Mean distance to road $(\mathrm{m})^{2,4}$ & $1,471.9$ & $1,604.9$ \\
\hline $\mathrm{GFC} 20^{2,3,4}$ & 75.3 & 97.2 \\
\hline $\mathrm{VCF}^{1,2}$ & 49.5 & 48.1 \\
\hline Mean total edge $(\mathrm{m})^{2}$ & $2,921.9$ & $1,023.3$ \\
\hline Mean total core area $\left(\mathrm{m}^{2}\right)^{2,4}$ & 30.3 & 42.6 \\
\hline Mean no. of patches ${ }^{3}$ & 7.7 & 3.0 \\
\hline Mean landscape patch index ${ }^{3}$ & 1.9 & 95.4 \\
\hline Mean distance to water $(\mathrm{m})^{2,4}$ & $2,127.1$ & 958.8 \\
\hline Drainage $(\mathrm{m})^{4}$ & $3,348.8$ & $1,088.5$ \\
\hline Mean elevation (m) & 146.3 & 26.4 \\
\hline \multicolumn{3}{|c|}{ Trap success (number of species detections/total sampling days $\times 100$ ) } \\
\hline Fosa Cryptoprocta ferox & 3.6 & 3.6 \\
\hline Dog Canis lupus familiaris ${ }^{1}$ & 13.7 & 3.9 \\
\hline Cat Felis sp. ${ }^{1}$ & 3.4 & 11.2 \\
\hline Civet Viverricula indica ${ }^{2,3}$ & 1.2 & 0.0 \\
\hline Pig Potamochoerus larvatus ${ }^{3}$ & 1.8 & 2.8 \\
\hline Zebu Bos primigenius indicus ${ }^{2,3}$ & 18.9 & 1.3 \\
\hline Lemur (multiple sp.) $)^{1,2}$ & 0.3 & 0.7 \\
\hline Bird (multiple sp.) $)^{1,3}$ & 3.2 & 6.6 \\
\hline Human & 104.8 & 32.2 \\
\hline
\end{tabular}

${ }^{1}$ Forest type, forest classification (old-growth, degraded, savannah); Trail type, game trail, Madagascar National Park trail, disused logging trail, trail actively used by local people; GFC20, mean \% global forest cover (forest cover at $20 \%$ threshold level at $30 \mathrm{~m}$ resolution); VCF, mean vegetation continuous field (\% forest cover at $250 \mathrm{~m}$ resolution; Drainage, mean distance $(\mathrm{m})$ to nearest drainage point (lowest point of elevation).

${ }^{2,3,4}$ Indicates the best performing uncorrelated covariates included in the final $\mathrm{fos}^{2}, \operatorname{dog}^{3}$ and cat ${ }^{4}$ occupancy models.

used as covariates. All detections within a 30-minute period were considered a single detection (Linkie \& Ridout, 2011). A complete camera-trap day involved at least one of two cameras operating during the 24 hours. Capture histories for each species were created through the collapsing of individual days into 5-day periods, improving temporal independence and model convergence (Otis et al., 1978). Species-level covariates were the encounter rates of exotic animals and humans at each camera-trap station and were calculated by evaluating trap success (number of detections/ total days $\times 100$ ) per species. Two survey covariates were included to account for detection probability: the site surveyed (Site), and the number of days a station was active during each 5-day sampling period (Effort).

Camera station-level covariates were included to assess the impact of station geography. Trail width, trail type and forest type were included as they have been reported to be important metrics in fosa occupancy (Farris et al., 2015b). Trail width was estimated by averaging the width of the trail at the camera-trap station and at $10 \mathrm{~m}$ either side. Forest type was categorized subjectively and visually as either old-growth (intact forest with some disturbance), degraded (low forest cover, with few native plant species) or savannah (anthropogenic grassland). Trail type was 
confirmed by a local guide and categorized as Madagascar National Park trail, local (actively used by local people), disused-local (formerly used by local people), game (animal trail), logging (actively used by loggers), or disused-logging (formerly used by loggers).

We used QGIS v. 2.12.1 (QGIS Development Team, 2015) and FRAGSTATS v. 4.2 (McGarigal et al., 2002) to create 12 landscape-level covariates, to examine the effects of human settlement, landscape degradation, and ecological variables on fosa occupancy (Table 1). A 500-m buffer was created around each camera-trap station and the mean value of the raster cells was calculated for each covariate.

Two metrics were used to measure forest cover: global forest cover (GFC; Hansen et al., 2013) and mean vegetation continuous field (VCF; DiMiceli et al., 2011). The per cent of GFC (which is at $30 \mathrm{~m}$ resolution) that can be classified as forest may be specified. We chose 10, 20, 30 and 50\% and compared these within univariate models to find the best predictor of fosa occupancy. VCF provides a forest cover per cent at $250 \mathrm{~m}$ map resolution. Maps of GFC for Andranomena Special Reserve were unavailable for thesurvey year, and therefore the most recently available (2014) maps were used. Four measures of fragmentation (Table 1; Gerber et al., 2012a; Farris et al., 2015b) were calculated with FRAGSTATS.

Two measures of water proximity were calculated using a waterway raster containing Madagascar's major water sources (Mapcruzin, 2016) and a digital elevation model (Jarvis et al., 2008), facilitating the mapping of low-elevation areas that may represent drainage points and potential seasonal streams. The covariate mean elevation was created from the Shuttle Radar Topography Mission's 90 m raster (Carroll et al., 2009).

We used the $R$ v. 3.3.3 (R Core Team, 2017) package unmarked v. o.11-o (Fiske \& Chandler, 2011) to run singlespecies, single-season occupancy modelling of the fosa, cat, and dog. Prior to modelling, a Pearson's correlation test was used to eliminate multicollinearity. We removed correlated continuous predictors $(r>0.6$; i.e. the predictor that performed worst in the univariate model) and normalized the remaining covariates. A stepwise approach was taken to reduce the total number of competing covariates to be included in each final occupancy model for fosa, cat and dog. Firstly, the detection probability was modelled, with the most significant combination of detection covariates (Site and Effort) selected. Secondly, potential occupancy covariates were modelled independently with selected detection covariates, with the best-performing uncorrelated covariates retained (Table 1). We used the Akaike information criterion (AIC) and model selection to rank competing models, and reported those with AIC $<2$.o. Covariates that attained a summed model weight $>0.50$ were considered to be important predictors of occupancy (Barbieri \& Berger, 2004).

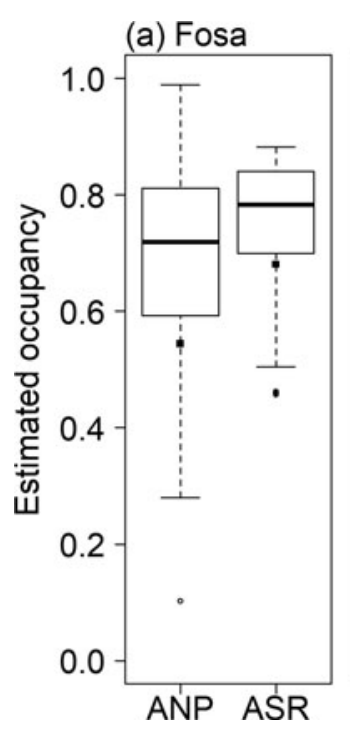

(b) Cat

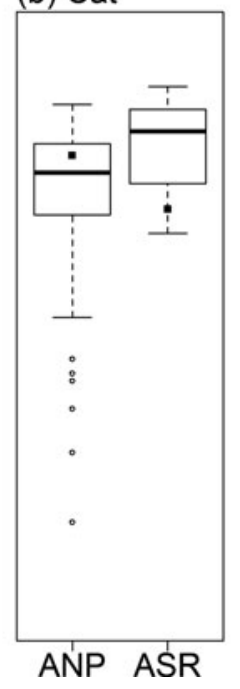

(c) Dog

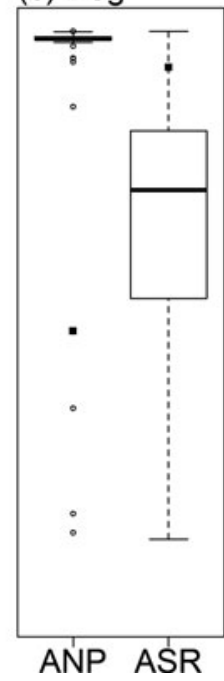

FIG. 2 Estimated site occupancy for the fosa Cryptoprocta ferox, cat Felis sp. and dog Canis lupus familiaris in Ankarafantsika National Park (ANP) and Andranomena Special Reserve (ASR) in Madagascar (Fig. 1). The boxes represent median site occupancy with upper and lower quartiles (25\% greater and $25 \%$ lesser than the median); whiskers represent maximum/minimum values, black dots naïve occupancy, and white dots outliers.

We ran a goodness-of-fit test to examine the model's likelihood of being correct $(\mathrm{P}>0.05)$ and determine how well it fitted the data (measuring overdispersion as $\hat{c}$ ). Species occupancy was predicted across both sites, accounting for the important covariate predictors.

\section{Results}

\section{Landscape features and site detections}

With a sampling effort of 8,730 nights across both sites, we recorded the presence of three native and three exotic carnivores (Table 1). The survey in Andranomena Special Reserve was shortened as a result of camera-trap theft ( 35 days vs 80 days in Ankarafantsika National Park). Overall, the landscape of the Park was more degraded (GFC 75.32\%) than that of the Reserve (GFC 97.16\%). The mean distance from camera stations to the nearest village and to the forest edge was considerably less in the Park than in the Reserve (Table 1).

In total, 311 independent detections of fosas were recorded (226 in the Park, 85 in the Reserve). In the Park, E. major was detected once, and in the Reserve $M$. decemlineata was detected twice. Small Indian civets were absent from the Reserve; in the Park they were detected almost exclusively in savannah and degraded land. These low detection rates prohibited occupancy modelling for these three species. Trap success was higher for dogs, zebu and humans in the Park, and for cats and birds in the Reserve (Table 1). 
TABLE 2 Species covariate occupancy models for fosa, cat and dog, with Akaike information criterion corrected for a small sample size $(\mathrm{AICc})$, relative change in Akaike information criterion from top model ( $\mathrm{AICc})$, Akaike weight (AICc weight), number of parameters $(\mathrm{K})$, and $-2 \log$ likelihood.

\begin{tabular}{|c|c|c|c|c|c|c|}
\hline Species & Occupancy model $^{1}$ & AICc & $\Delta \mathrm{AICc}$ & AICc weight & $\mathrm{K}$ & -2 log likelihood \\
\hline \multirow[t]{9}{*}{ Fosa } & Cat + Dog + GFC20 + TCA & $1,195.32$ & 0.00 & 0.08 & 8 & -589.11 \\
\hline & Cat + Dog + GFC20 & $1,195.54$ & 0.22 & 0.07 & 7 & -590.34 \\
\hline & Cat + GFC20 & $1,195.81$ & 0.49 & 0.06 & 6 & -591.59 \\
\hline & $\mathrm{Cat}+\mathrm{Dog}+\mathrm{TCA}$ & $1,195.85$ & 0.53 & 0.06 & 7 & -590.50 \\
\hline & $\mathrm{Cat}+\mathrm{Dog}+\mathrm{GFC} 20+\mathrm{TCA}+\mathrm{TW}$ & $1,196.20$ & 0.89 & 0.05 & 9 & -588.41 \\
\hline & Cat + Dog + Road + TCA & $1,196.30$ & 0.99 & 0.05 & 8 & -589.60 \\
\hline & $\mathrm{Cat}+\mathrm{Dog}+\mathrm{GFC} 20+\mathrm{TW}$ & $1,196.41$ & 1.09 & 0.04 & 8 & -589.65 \\
\hline & Cat + Dog + GFC20 + Lemur & $1,196.44$ & 1.12 & 0.04 & 8 & -589.67 \\
\hline & Cat + Dog + GFC20 + Lemur + TCA & $1,196.49$ & 1.17 & 0.04 & 9 & -588.55 \\
\hline \multirow[t]{2}{*}{ Cat } & Bird + TW + VCF & $1,558.00$ & 0.00 & 0.23 & 7 & -771.59 \\
\hline & Bird + TW & $1,558.33$ & 0.33 & 0.20 & 6 & -772.86 \\
\hline \multirow[t]{6}{*}{ Dog } & Civet + Forest $+\mathrm{NP}+\mathrm{TW}$ & $1,288.57$ & 0.00 & 0.10 & 9 & -634.55 \\
\hline & Forest + Lemur + NP + TW & $1,288.68$ & 0.11 & 0.09 & 9 & -634.61 \\
\hline & Civet + TW + VCF & $1,289.17$ & 0.60 & 0.07 & 7 & -637.14 \\
\hline & $\mathrm{FD}+$ Forest + Lemur $+\mathrm{NP}+\mathrm{TW}$ & $1,289.46$ & 0.89 & 0.06 & 10 & -633.83 \\
\hline & Civet + FD + Forest $+\mathrm{NP}+\mathrm{TW}$ & $1,289.51$ & 0.94 & 0.06 & 10 & -633.85 \\
\hline & Forest + NP + TW + Zebu & $1,289.56$ & 0.99 & 0.06 & 9 & -635.05 \\
\hline
\end{tabular}

${ }^{1}$ Cat, Dog, Lemur, Bird, Civet and Zebu, species encounter rates (total detections/total sampling days $\times 100$ ); GFC20, \% global forest cover at $20 \%$ threshold level (30 m resolution); TCA, total core area in each patch $\left(\mathrm{m}^{2}\right)$; TW, trail width $(\mathrm{m})$; VCF, vegetation continuous field (\% forest cover at $250 \mathrm{~m}$ resolution); Forest, forest classification (old-growth, degraded, savannah); NP, total patches of a class type; FD, distance to forest edge (m).

\section{Covariate and model validation}

Our two survey covariates (Site and Effort) were contained in the best performing detection model (Supplementary Table 1). Consequently, they were included in all subsequent modelling of occupancy with occupancy covariates. Our correlation matrix revealed significant correlations between competing covariates (Supplementary Table 2). Six covariates (Number of patches, Landscape patch index, VCF, Elevation, Mean distances to village and forest) were discarded prior to constructing the multivariate fosa occupancy model. The goodness-of-fit test indicated significant overdispersion, and consequently five sites were removed ( 42 detections in total).

\section{Occupancy}

There were no statistically significant differences in occupancy between the two study sites $(\mathrm{P}<0.05)$. The mean fosa occupancy across both regions was 0.724 , being marginally higher in the Reserve (0.757) than in the Park (0.692; $\chi^{2}=0.003, \mathrm{df}=1, \mathrm{P}=0.959$; Fig. 2 ). Mean cat occupancy was 0.736 , and was marginally higher in the Reserve $\left(\chi^{2}=2.844, \mathrm{df}=1, \mathrm{P}=0.092\right)$. Mean dog occupancy was 0.999, and was considerably higher in the Park $\left(\chi^{2}=2.306\right.$, $\mathrm{df}=1, \mathrm{P}=0.129$ ).

Cat and dog trap success, GFC20 and total core area were the most important covariates (summed model weight $>0.5$; Supplementary Table 3) in explaining fosa occupancy across the landscape (Table 2). Dog trap success had a weak positive relationship with fosa occupancy, whereas cat trap success, GFC20 and total core area had a negative relationship with fosa occupancy (Table 3 ).

Cat occupancy was best explained by bird trap success, trail width and VCF (Table 2). Bird trap success and trail width were negatively correlated with cat occupancy, whereas there was a positive association between occupancy and VCF (Table 3 ).

Dog occupancy was best explained by civet trap success, forest type, number of patches and trail width (Table 2). Civet trap success and trail width were positively correlated with dog occupancy, whereas old-growth, savannah and total patches negatively affected occupancy (Table 3).

\section{Discussion}

Overall our results were unclear regarding the relationship between the fosa, landscape degradation and exotic species, with no clear relationship evident between fosas and degradation, but a clear negative relationship between fosas and cats. Our findings regarding dog and cat occupancy concur with previous studies documenting the negative effect of exotic species on Madagascar's endemic carnivores (Gerber et al., 2012a; Farris et al., 2015b, 2016; Murphy et al., 2017). The fosa appears to be more resilient to habitat disturbance within contiguous forests than other euplerids but the loss of Madagascar's forest is likely to inhibit their long-term persistence. The high occupancy of free-ranging cats and dogs in the landscape indicates considerable competition with fosas through the consumption of shared prey (Brockman et al., 2008) and exclusion from habitat. The 
TABLE 3 Landscape single-season occupancy models for fosa, cat and dog, including all best performing, uncorrelated covariates. Model data were from camera-trap surveys conducted in Ankarafantsika National Park and Andranomena Special Reserve, Madagascar (Fig. 1) during 2014-2015.

\begin{tabular}{|c|c|c|c|c|c|}
\hline Model & Covariate $^{1}$ & Estimate & SE & $\mathrm{z}$ & $\mathrm{P}(>|z|)$ \\
\hline \multirow[t]{12}{*}{ Fosa } & (Intercept) & 1.023 & 0.414 & 2.471 & 0.014 \\
\hline & Trail width & -0.331 & 0.281 & -1.177 & 0.239 \\
\hline & Cat trap success & -0.915 & 0.429 & -2.134 & 0.033 \\
\hline & GFC20 & -0.986 & 0.895 & -1.102 & 0.271 \\
\hline & Total edge & -0.542 & 0.505 & -1.074 & 0.283 \\
\hline & Total core area & -0.658 & 0.383 & -1.719 & 0.086 \\
\hline & Village distance & 0.252 & 0.406 & 0.621 & 0.534 \\
\hline & Dog trap success & 0.891 & 0.585 & 1.524 & 0.127 \\
\hline & Lemur trap success & -0.352 & 0.303 & -1.160 & 0.246 \\
\hline & Water distance & 0.138 & 0.302 & 0.456 & 0.648 \\
\hline & Road distance & -0.071 & 0.496 & -0.143 & 0.887 \\
\hline & Bird trap success & -0.262 & 0.353 & -0.741 & 0.459 \\
\hline \multirow[t]{12}{*}{ Cat } & (Intercept) & 1.080 & 0.593 & 1.823 & 0.068 \\
\hline & Trail width & 0.012 & 0.228 & 0.050 & 0.960 \\
\hline & Bird trap success & -0.615 & -0.325 & 1.892 & 0.059 \\
\hline & Civet trap success & -0.664 & -0.374 & 0.483 & 0.629 \\
\hline & VCF & 0.434 & 0.273 & 1.588 & 0.112 \\
\hline & Forest distance & 0.082 & 0.482 & 0.171 & 0.865 \\
\hline & Drainage & 0.111 & 0.355 & 0.314 & 0.754 \\
\hline & Zebu trap success & 0.030 & 0.340 & 0.088 & 0.930 \\
\hline & Water distance & 0.336 & 0.274 & 1.227 & 0.220 \\
\hline & Pig trap success & 0.654 & 0.536 & 1.219 & 0.223 \\
\hline & Road distance & 0.048 & 0.263 & 0.181 & 0.857 \\
\hline & Total core area & -0.092 & -0.257 & 0.359 & 0.720 \\
\hline \multirow[t]{15}{*}{ Dog } & (Intercept) & 17.252 & 18.983 & 0.909 & 0.363 \\
\hline & Trail width & 0.459 & 0.575 & 0.798 & 0.425 \\
\hline & Civet trap success & 2.682 & 5.059 & 0.530 & 0.596 \\
\hline & Lemur trap success & 2.578 & 6.223 & 0.414 & 0.679 \\
\hline & Zebu trap success & 1.336 & 2.638 & 0.506 & 0.613 \\
\hline & Forest distance & -0.472 & 1.152 & -0.410 & 0.682 \\
\hline & Landscape patch index & -0.973 & 0.875 & -1.111 & 0.266 \\
\hline & Forest: old-growth & -8.321 & 12.923 & -0.644 & 0.520 \\
\hline & Forest: savannah & -6.867 & 13.027 & -0.527 & 0.598 \\
\hline & VCF & 1.588 & 1.232 & 1.289 & 0.197 \\
\hline & Number of patches & -1.498 & 1.102 & -1.359 & 0.174 \\
\hline & Trail: game & 7.043 & 152.808 & 0.046 & 0.963 \\
\hline & Trail: MNP & -4.115 & 13.577 & -0.303 & 0.762 \\
\hline & Trail: disused logging & 3.699 & 65.202 & 0.057 & 0.955 \\
\hline & Trail: local & -4.241 & 13.580 & -0.312 & 0.755 \\
\hline
\end{tabular}

${ }^{1}$ Trail width, mean trail width (m); Trap success (cat, dog, lemur, bird, civet, zebu, pig), species encounter rates (total detections/total sampling days $\times 100$ ); GFC2O, \% global forest cover at 20\% threshold level (30 m resolution); Total edge, sum of all edge segments in camera-trap buffer; Total core area, in each patch $\left(\mathrm{m}^{2}\right)$; Village/Water/Road/Forest distance, mean distance $(\mathrm{m})$ to nearest village/water source/road/forest edge; VCF, vegetation continuous field (\% forest cover at $250 \mathrm{~m}$ resolution); Drainage, mean distance $(\mathrm{m})$ to nearest drainage point (lowest point of elevation); Landscape patch index (\% of landscape in the largest patch); Forest, forest classification (old-growth, degraded, savannah); Number of patches, number of patches of a class type; Trail: game, game trail; Trail: MNP, Madagascar National Park trail; Trail: disused logging, disused logging trail; Trail: local, trail actively used by local people.

spread of disease, such as toxoplasmosis (Pomerantz et al., 2016; Rasambainarivo et al., 2017), between exotic species, fosas and their prey is of concern, potentially imperilling the health of the fosa population in the long term.

\section{Effect of exotic species on fosa occupancy}

Cats had the strongest negative association with fosa occupancy. It is widely acknowledged that cats have a negative impact on native wildlife through predation, competition, hybridization and disease (Medina et al., 2011). In Madagascar predation on endemic species by cats has been reported (Sauther, 1989; Goodman et al., 1993; Brockman et al., 2008), and in Andranomena Special Reserve cats were photographed with a red-fronted brown lemur Eulemur rufus and speckled hognose snake Leioheterodon geayi (Plate 1). In our study the number of cats recorded was negatively associated with bird presence, a relationship reported previously in 
(a)

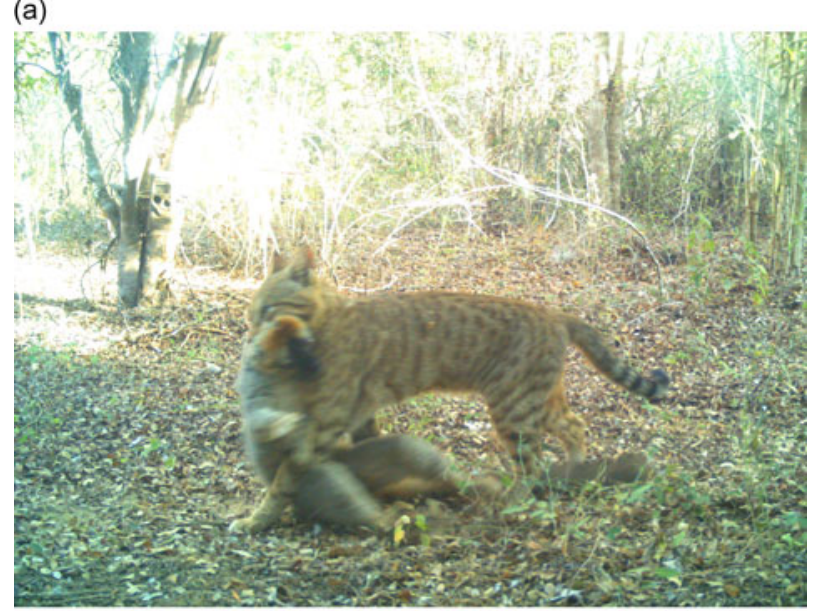

(b)

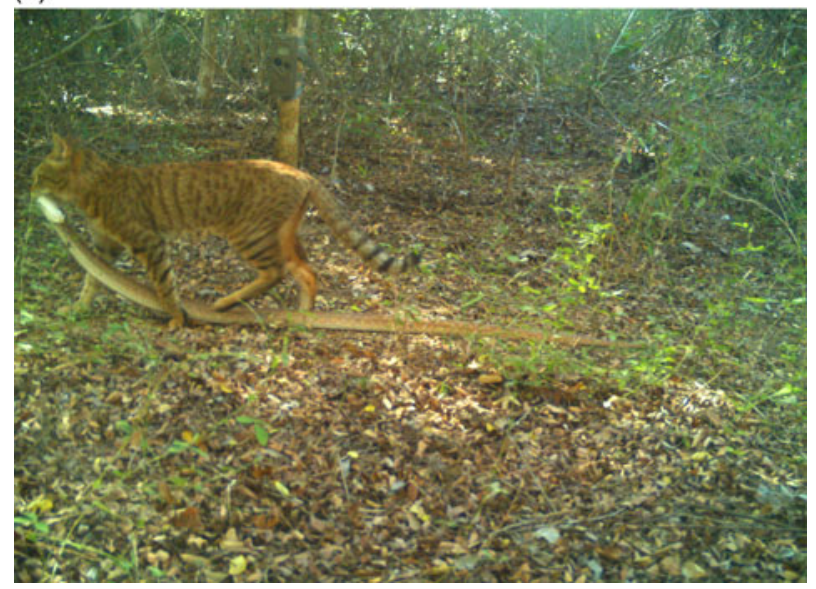

Plate 1 Wild cats Felis sp. preying on (a) a red-fronted brown lemur Eulemur rufus and (b) a speckled hognose snake Leioheterodon geayi in Andranomena Special Reserve, Madagascar (Fig. 1).

Masoala-Makira (Murphy et al., 2018a); negative associations have also been recorded between cats and the rainforestdwelling euplerids Galidia elegans and Fossa fossana (Gerber et al., 2012a; Farris et al., 2015b). Collectively these results suggest that cats are probably having a negative impact on the fosa and other endemic species, at the very least through direct predation and competition for prey.

In concordance with previous studies in rainforest, dogs did not have a negative association with fosa occupancy (Gerber et al., 2012a; Farris et al., 2015b). This is in contrast with the reported impact of dogs on the euplerid Galidictis fasciata (Gerber et al., 2012a) and incongruous with the damaging effects of dogs globally (Hughes \& Macdonald, 2013). However, activity pattern analyses have indicated fosas display temporal activity shifts towards greater nocturnality (Farris et al., 2015a; Merson, 2018), and/or absence from sites with higher frequency of dog detections (Gerber et al., 2012a; Farris et al., 2015b). The sociality and size of dog packs (L.J. Dollar, unpubl. data) may be a source of interference competition for fosas, but the predatory impact of dogs on Madagascar's ecosystem is still being investigated.

Disease transmission from cats and dogs is a significant threat to the long-term health of endemic species. Fatal cases of Toxoplasma gondii infection have been recorded in captive fosas (Corpa et al., 2013) and lemurs (Juan-Sallés et al., 2011; Siskos et al., 2015), highlighting their vulnerability to lethal infections. Field studies of exotic carnivores in Ankarafantsika National Park have identified the occurrence of multiple viruses and parasites, including canine parovirus, feline calicivirus and T. gondii (Pomerantz et al., 2016), the latter prevalent in $>93 \%$ of captured wild fosas. The detrimental impact of disease on Madagascar's wild fosa populations could be significant, reflecting disease-related species population declines elsewhere (Pedersen et al., 2007).

\section{Habitat degradation impact on fosa occupancy}

Fosa occupancy was higher in Andranomena Special Reserve, possibly because of greater forest cover, and lower dog and human presence. However, within our models fosa occupancy was not influenced by any habitat degradation parameters, with results similar to those reported for Madagascar's rainforests (Gerber et al., 2012a; Farris et al., 2015b). Despite this, surveys have not recorded fosas in areas $>5 \mathrm{~km}$ from the nearest contiguous forest (Kotschwar Logan et al., 2015) or in forest fragments $>2.5 \mathrm{~km}$ from the nearest contiguous forest (Gerber et al., 2012a). This suggests that despite their resilience to habitat degradation within contiguous forest, fosas are unable to persist far from intact forest. Considering Madagascar's highly fragmented forests (Vieilledent et al., 2018), it is likely that most forest areas are of insufficient size to support fosa populations in the long term (Hawkins \& Racey, 2005).

Cat occupancy was higher in the Reserve, positively associated with higher vegetation cover and weakly associated with narrow trails. This could be attributed to their avoidance of larger carnivores (dogs, fosas) and people. Farris et al. (2015b) found similar positive associations with forest cover, possibly confirming their preference for areas of greater prey abundance.

Dogs had the highest occupancy in the Park. They had a positive association with large trails, and civets, and a negative association with old-growth forest, and savannah, possibly explained by dogs accompanying people during forest-related activities. This was apparent in the Park, where the forest surrounding rural villages encompassed a mixture of savannah and degraded forest, with high presence of people and exotic species (e.g. zebu, civet).

\section{Long-term implications}

Looking beyond the snapshot view of single-season occupancy models, recent multi-year studies in north-eastern Madagascar recorded occupancy of endemic and exotic 
carnivores, indicating long-term decline and replacement of endemic species by exotic species (Farris et al., 2016). In Ranomafana National Park a multi-year occupancy study reported the long-term decline of fosas, their strong cooccurrence with dogs being a likely source of competition or disease (Farris et al., 2017). This supports our speculation that fosa resilience to habitat degradation inside contiguous forests is probably short-term, with a long-term population decline evident (Hawkins, 2016). This is largely the result of the severe reduction of Madagascar's forests, the killing of fosas for bushmeat and in retaliation for poultry depredation, and the increase in abundance of dogs and cats, increasing competition and disease transmission. Steps to mitigate the impact of exotic species on fosas and the ecosystem as a whole need to be explored. Sterilization programmes for domestic cats and dogs, along with culling of free-ranging cats and dogs should be trialled to evaluate their effectiveness in improving the abundance of native species. If they prove to be both cost-effective and beneficial to the ecosystem, we propose the incorporation of these programmes into an island-wide forest management strategy.

Acknowledgements We thank World Animal Protection, Megafaun and the Fossa Fund of Duisburg Zoo for funding this research, and the organizations and individuals who facilitated our research: MICET, Fanamby and our field research team, Fenohery, Solonantenaina, Naina, Noelson, Frederick, Domoina, Sierra, and our friend Pierrot Rahajanirina, you will be missed. Our deepest gratitude to the Malagasy communities who accommodated us. We thank the Madagascar Government, and National Parks for authorizing this research (permits 107/14 and 109/15/MEEMF/SG/DGF/DCB.SAPT/SCB).

Author contributions Study design, research, data analysis, writing: SDM; data analysis and writing: CKWT; study design and writing: DWM, LJD.

\section{Conflicts of interest None.}

Ethical standards This research complies with Oryx's Code of Conduct for authors.

\section{References}

Allnutt, T.F., Asner, G.P., Golden, C.D. \& Powell, G.V.N. (2013) Mapping recent deforestation and forest disturbance in northeastern Madagascar. Tropical Conservation Science, 6, 1-15.

Barbieri, M.M. \& Berger, J.O. (2004) Optimal predictive model selection. The Annals of Statistics, 32, 870-897.

Brockman, D.K., Godfrey, L.R., Dollar, L.J. \& Ratsirarson, J. (2008) Evidence of invasive Felis silvestris predation on Propithecus verreauxi at Beza Mahafaly Special Reserve, Madagascar. International Journal of Primatology, 29, 135-152.

Carroll, M.L., Townshend, J.R., DiMiceli, C.M., Noojipady, P. \& SohlberG, R.A. (2009) A new global raster water mask at $250 \mathrm{~m}$ resolution. International Journal of Digital Earth, 2, 291-308.

Corpa, J.M., García-Quirós, A., Casares, M., Gerique, A.C., Carbonell, M.D., Gómez-Muñoz, M.T. et al. (2013) Encephalomyelitis by Toxoplasma gondii in a captive fossa (Cryptoprocta ferox). Veterinary Parasitology, 193, 281-283.
DiMiceli, C.M., Carroll, M.L., Sohlberg, R.A., Huang, C., Hansen, M.C. \& Townshend, J.R.G. (2011) Annual Global Automated MODIS Vegetation Continuous Fields (MOD44B) at 250 m Spatial Resolution for Data Years Beginning day 65, 2000-2010, Collection 5 Percent Tree Cover. University of Maryland, College Park, USA.

Dollar, L.J. (2006) Morphometrics, diet, and conservation of Cryptoprocta ferox. PhD thesis. Duke University, Durham, USA.

Dollar, L., Ganzhorn, J. \& Goodman, S. (2007) Primates and other prey in the seasonally variable diet of Cryptoprocta ferox in the dry deciduous forest of western Madagascar. In Primate Anti-Predator Strategies (eds S. Gursky \& K.A.I. Nekaris), pp. 63-76. Springer, New York, USA.

Farris, Z.J., Karpanty, S.M., Ratelolahy, F. \& Kelly, M.J. (2014) Predator-primate distribution, activity, and co-occurrence in relation to habitat and human activity across fragmented and contiguous forests in northeastern Madagascar. International Journal of Primatology, 35, 859-880.

Farris, Z.J., Gerber, B.D., Karpanty, S., Murphy, A., Andrianjakarivelo, V., Ratelolahy, F. \& Kelly, M.J. (2015a) When carnivores roam: temporal patterns and overlap among Madagascar's native and exotic carnivores. Journal of Zoology, 296, 45-57.

Farris, Z.J., Golden, C.D., Karpanty, S., Murphy, A., Stauffer, D., Ratelolahy, F. et al. (2015b) Hunting, exotic carnivores, and habitat loss: anthropogenic effects on a native carnivore community, Madagascar. PLOS ONE, 10, e0136456.

Farris, Z.J., Kelly, M.J., Karpanty, S. \& Ratelolahy, F. (2015c) Patterns of spatial co-occurrence among native and exotic carnivores in north-eastern Madagascar. Animal Conservation, 19, 189-198.

Farris, Z.J., Kelly, M.J., Karpanty, S., Murphy, A., Ratelolahy, F., Andrianja Karivelo, V. \& Holmes, C. (2016) The times they are a changin': multi-year surveys reveal exotics replace native carnivores at a Madagascar rainforest site. Biological Conservation, 206, 320-328.

Farris, Z.J., Gerber, B.D., Valenta, K., Rafaliarison, R., Razafimahaimodison, J.C., Larney, E. et al. (2017) Threats to a rainforest carnivore community: a multi-year assessment of occupancy and co-occurrence in Madagascar. Biological Conservation, 210, 116-124.

Fiske, I. \& Chandler, R. (2011) unmarked: An $R$ package for fitting hierarchical models of wildlife occurrence and abundance. Journal of Statistical Software, 43, 1-23.

GaRdNER, C.J. (2009) A review of the impacts of anthropogenic habitat change on terrestrial biodiversity in Madagascar: implications for the design and management of new protected areas. Malagasy Nature, 2, 2-29.

Gerber, B.D., Karpanty, S.M. \& Randrianantenaina, J. (2012a) The impact of forest logging and fragmentation on carnivore species composition, density and occupancy in Madagascar's rainforests. Oryx, 46, 414-422.

Gerber, B.D., Karpanty, S.M., Randrianantenaina, J. (2012b) Activity patterns of carnivores in the rain forests of Madagascar: implications for species coexistence. Journal of Mammalogy, 93, 667-676.

Golden, C.D. (2009) Bushmeat hunting and use in the Makira Forest, north-eastern Madagascar: a conservation and livelihoods issue. Oryx, 43, 386-392.

Goodman, S.M., O'Connor, S. \& Langrand, O. (1993) A review of predation on lemurs: implications for the evolution of social behavior in small, nocturnal primates. In Lemur Social Systems and their Ecological Basis (eds P.M. Kappeler \& J.U. Ganzhorn), pp. 51-66. Springer, New York, USA.

Hansen, M.C., Potapov, P.V., Moore, R., Hancher, M., Turubanova, S.A., Tyukavina, A. et al. (2013) High-resolution global maps of 21st-century forest cover change. Science, 342, 850-853. 
HaW KIns, C.E. (1998) Behaviour and ecology of the fossa, Cryptoprocta ferox (Carnivora: Viverridae) in a dry deciduous forest, western Madagascar. PhD thesis. University of Aberdeen, Aberdeen, UK. Hawkins, F. (2016) Cryptoprocta ferox. In The IUCN Red List of Threatened Species 2016: e.T5760A45197189. Http://dx.doi.org/10. 2305/IUCN.UK.2016-1.RLTS.T5760A45197189.en [accessed 17 November 2014].

Hawkins, C.E. \& RaceY, P.A. (2005) Low population density of a tropical forest carnivore, Cryptoprocta ferox: implications for protected area management. Oryx, 39, 35-43.

Hawkins, C.E. \& RaCEY, P.A. (2008) Food habits of an endangered carnivore, Cryptoprocta ferox, in the dry deciduous forests of western Madagascar. Journal of Mammalogy, 89, 64-74.

Hughes, J. \& Macdonald, D.W. (2013) A review of the interactions between free-roaming domestic dogs and wildlife. Biological Conservation, 157, 341-351.

Irwin, M.T., Wright, P.C., Birkinshaw, C., Fisher, B.L., Gardner, C.J., Glos, J. et al. (2010) Patterns of species change in anthropogenically disturbed forests of Madagascar. Biological Conservation, 143, 2351-2362.

Jarvis, A., Reuter, H.I., Nelson, A. \& Guevara, E. (2008) Hole-filled SRTM for the Globe, Version 4. Available from the CGIAR-CSI SRTM 9om Database. Http://srtm.csi.cgiar.org [accessed 21 January 2019].

Juan-Sallés, C., Mainez, M., Marco, A. \& Malabia Sanchís, A.M. (2011) Localized toxoplasmosis in a ring-tailed lemur (Lemur catta) causing placentitis, stillbirths, and disseminated fetal infection. Journal of Veterinary Diagnostic Investigation, 23, 1041-1045.

Kotschwar Logan, M., Gerber, B.D., Karpanty, S.M., Justin, S. \& Rabenahy, F.N. (2015) Assessing carnivore distribution from local knowledge across a human-dominated landscape in central-southeastern Madagascar. Animal Conservation, 18, 82-91.

Linkie, M. \& Ridout, M.S. (2011) Assessing tiger-prey interactions in Sumatran rainforests. Journal of Zoology, 284, 224-229.

LÜhrs, M.L. \& Kappeler, P.M. (2013) Simultaneous GPS tracking reveals male associations in a solitary carnivore. Behavioral Ecology and Sociobiology, 67, 1731-1743.

MacKenzie, D.I., Nichols, J.D., Royle, J.A., Pollock, K.H., BAiley, L.L. \& Hines, J.E. (2006) Occupancy Estimation and Modeling: Inferring Patterns and Dynamics of Species Occurrence. Academic Press, Burlington, USA.

MacKenzie, D.I. \& Nichols, J.D. (2004) Occupancy as a surrogate for abundance estimation. Animal Biodiversity and Conservation, $27,461-467$.

MAPCRUZIN (2016) Madagascar Waterways. Http://www.mapcruzin. com/free-madagascar-arcgis-maps-shapefiles.htm [accessed 7 August 2016].

McGarigal, K., Cushman, S.A., Neel, M.C. \& Ene, E. (2002) FRAGSTATS: Spatial Pattern Analysis Program for Categorical Maps. University of Massachusetts, Amherst, USA. Http://www. umass.edu/landeco/research/fragstats/fragstats.html [accessed 21 January 2019].

Medina, F.M., Bonnaud, E., Vidal, E., Tershy, B.R., Zavaleta, E.S., Josh Donlan, C. et al. (2011) A global review of the impacts of invasive cats on island endangered vertebrates. Global Change Biology, 17, 3503-3510.

Merson, S.D. (2018) Bushmeat hunting, retaliatory killing, habitat degradation and exotic species as threats to fosa (Cryptoprocta ferox) conservation. $\mathrm{PhD}$ thesis. University of Oxford, Oxford, UK.

Merson, S.D., Macdonald, D.W. \& Dollar, L.J. (2018) Novel photographic and morphometric records of the western falanouc Eupleres major in Ankarafantsika National Park, Madagascar. Small Carnivore Conservation, 56, 60-67.
Murphy, A.J., Farris, Z.J., Karpanty, S., Kelly, M.J., Miles, K.A., Ratelolahy, F. et al. (2018a) Using camera traps to examine distribution and occupancy trends of ground-dwelling rainforest birds in north-eastern Madagascar. Bird Conservation International, $28,567-580$.

Murphy, A.J., Goodman, S.M., Farris, Z.J., Karpanty, S.M., Andrianjakarivelo, V. \& Kelly, M.J. (2017) Landscape trends in small mammal occupancy in the Makira-Masoala protected areas, northeastern Madagascar. Journal of Mammalogy, 98, 272-282.

Murphy, A., Gerber, B., Farris, Z., Karpanty, S., Ratelolahy, F. \& Kelly, M. (2018b) Making the most of sparse data to estimate density of a rare and threatened species: a case study with the fosa, a little-studied Malagasy carnivore. Animal Conservation, 21, 496-504.

O’Connell, A.F., Nichols, J.D. \& Karanth, K.U. (eds) (2010) Camera Traps in Animal Ecology: Methods and Analyses. Springer, New York, USA.

Otis, D.L., Burnham, K.P., White, G.C. \& Anderson, D.R. (1978) Statistical inference from capture data on closed animal populations. Wildlife Monographs, 62, 3-135.

Pedersen, A.B., Jones, K.E., Nunn, C.L. \& Altizer, S. (2007) Infectious diseases and extinction risk in wild mammals. Conservation Biology, 21, 1269-1279.

Pomerantz, J., Rasambainarivo, F.T., Dollar, L., Rahajanirina, L.P., Andrianaivoarivelo, R., Parker, P. \& Dubovi, E. (2016) Prevalence of antibodies to selected viruses and parasites in introduced and endemic carnivores in western Madagascar. Journal of Wildlife Diseases, 52, 544-552.

QGIS Development Team (2015) QGIS Geographic Information System. Open Source Geospatial Foundation Project. Http://qgis.osgeo.org [accessed 21 January 2019].

Rasambainarivo, F., Farris, Z.J., Andrianalizah, H. \& Parker, P.G. (2017) Interactions between carnivores in Madagascar and the risk of disease transmission. EcoHealth, 14, 691-703.

R Core TeAm (2017) R: a Language and Environment for Statistical Computing. R Foundation for Statistical Computing, Vienna, Austria. Http://www.R-project.org [accessed February 2017].

Ripple, W.J., Estes, J.A., Beschta, R.L., Wilmers, C.C., Ritchie, E. G., Hebilewhite, M. et al. (2014) Status and ecological effects of the world's largest carnivores. Science, 343, 1241484.

SAUther, M.L. (1989) Antipredator behavior in troops of free-ranging Lemur catta at Beza Mahafaly Special Reserve, Madagascar. International Journal of Primatology, 10, 595-606.

SCALES, I.R. (2012) Lost in translation: conflicting views of deforestation, land use and identity in western Madagascar. The Geographical Journal, 178, 67-79.

Siskos, N., Lampe, K., Kaup, F.-J. \& Mätz-Rensing, K. (2015) Unique case of disseminated toxoplasmosis and concurrent hepatic capillariasis in a ring-tailed lemur: first case description. Primate Biology, 2, 9-12.

Vieilledent, G., Grinand, C., Rakotomalala, F.A., Ranaivosoa, R., Rakotoarijaona, J.-R., Allnutt, T.F. \& Achard, F. (2018) Combining global tree cover loss data with historical national forest cover maps to look at six decades of deforestation and forest fragmentation in Madagascar. Biological Conservation, 222, 189-197.

Waeber, P.O., Wilmé, L., Ramamonjisoa, B., Garcia, C., Rakotomalala, D., Rabemananjara, Z.H. et al. (2015) Dry forests in Madagascar: neglected and under pressure. International Forestry Review, 17, 127-148.

Zinner, D., Wygoda, C., RaZafimanantsoa, L., Rasoloarison, R., Andrianandrasana, H.T., Ganzhorn, J.U. \& Torkler, F. (2014) Analysis of deforestation patterns in the central Menabe, Madagascar, between 1973 and 2010. Regional Environmental Change, 14, 157-166. 